\title{
EKSISTENSI SATUAN PERLINDUNGAN MASYARAKAT
}

\section{The Existence of Public Protection Unit}

\author{
Moh. Ilham A. Hamudy \\ Pusat Penelitian Pemerintahan Umum dan Kependudukan \\ Badan Penelitian dan Pengembangan (BPP) Kementerian Dalam Negeri \\ Jl. Kramat Raya No. 132 - Senen, Jakarta \\ E-mail: ilhamhamudy80@gmail.com
}

Dikirim: 8 September 2014; direvisi: 23 November 2014; disetujui: 12 Desember 2014

\begin{abstract}
Abstrak
Artikel ini adalah tentang Satuan Perlindungan Masyarakat (Satlinmas) yang dulu dikenal dengan istilah pertahanan sipil (Hansip). Artikel ini adalah ringkasan hasil kajian pustaka dan uji petik di lapangan yang dilakukan pada Oktober-November 2013 di Kota Magelang dan Surabaya. Kajian ini bertujuan menelaah secara historis dan filosofis tentang eksistensi Satlinmas dalam konteks kekinian. Untuk mendalaminya, kajian ini menggunakan metode deskriptif dipadukan pendekatan kualitatif untuk menggali peran dan eksistensi Satlinmas. Hasil kajian menunjukkan, keberadaan Satlinmas masih meninggalkan banyak persoalannya, di antaranya, pertama, mengenai dasar hukum pembentukan Satlinmas. Sampai kini, belum ada regulasi baru yang mengatur Satlinmas. Regulasi yang ada sudah terlalu uzur dan tidak bisa menangkap perkembangan zaman. Kedua, rumusan konsep dan tugas pokok dan fungsi Satlinmas tumpang tindih dengan institusi lain. Ketiga, citra Satlinmas di masyarakat semakin memudar dan cenderung dilecehkan. Keempat, penggabungan Satlinmas ke dalam Polisi Pamong Praja dianggap tidak tepat, karena beda filosofi.

Kata kunci: satuan perlindungan masyarakat, pertahanan sipil, bencana alam, ketentraman dan ketertiban masyarakat, dan sistem keamanan lingkungan
\end{abstract}

\begin{abstract}
This articel is about the Public Protection Unit (Satlinmas) formerly known as civil defense (Hansip). This article is a summary of the results of the desk study and fieldwork conducted in October-November 2013 in the town of Magelang and Surabaya. This study used descriptive qualitative approach to explore the combined role and existence Satlinmas. The results of the study showed, the existence of the problem Satlinmas still leave many, including, first, the legal basis for the establishment of Satlinmas. Until now, there has been no new regulations governing Satlinmas. Existing regulations are too weak and can not capture the times. Second, the formulation of concepts and basic tasks and functions Satlinmas overlap with other institutions. Third, Satlinmas image in society tend to fade and abused. Fourth, Satlinmas incorporation into the Municipal Police deemed not appropriate, because different philosophy.

Keywords: public protection unit, civil defence, natural disasters, peace and order society, and environmental safety systems
\end{abstract}

\section{PENDAHULUAN}

Judul di atas senyatanya tidaklah berlebihan jika kita jujur menilai eksistensi Satuan Perlindungan Masyarakat (Satlinmas) dewasa ini. Kondisi Satlinmas terkesan ala kadarnya kalau tidak mau dikatakan memprihatinkan.

Tidak ada keunggulan khusus, sehingga patut dipersoalkan keberadaannya. Sejauh ini, Satlinmas hanya dikenal sebagai penjaga keamanan kantor desa/kelurahan/kecamatan atau pun sekadar menjadi satuan "seksi sibuk" saat ada kenduri di rumah warga.

Padahal, dilihat dari definisinya, menurut Peraturan Menteri Dalam Negeri (Permendagri) No. 6 Tahun 2012 tentang Kewaspadaan Dini Masayarakat di Daerah, Satlinmas adalah bentuk pengorganisasian masyarakat yang disiapkan dan disusun serta dibekali pengetahuan dan keterampilan di bidang perlindungan masyarakat yang difasilitasi oleh pemerintah atau pemerintah daerah.
Praktik di lapangan juga menunjukkan, Satlinmas merupakan warga masyarakat yang ikut memelihara keamanan, ketentraman dan ketertiban masyarakat, termasuk kegiatan sosial kemasyarakatan. Namun, fungsi-fungsi itu sekarang seakan tidak memunyai greget lagi dan pudar di mata masyarakat. Fungsinya direduksi sebagai penjaga gardu ronda dan pukul kentongan.

Malahan, di tengah pamornya yang memudar, Satlinmas pun digelayuti sejumlah persoalan. Pasalnya, sebagian besar anggota Satlinmas tampak uzur dan berpenampilan lemah fisik. Sementara, untuk mencari pengganti anggota yang sudah uzur, sekarang ini sangat sulit. Para pemuda pada umumnya tidak mau menjadi anggota Satlinmas. Selain honornya kecil, gengsinya pun masih kalah jauh dengan Satuan Polisi Pamong Praja (Satpol PP).

Kondisi ini agak berbeda dengan Satlinmas di Kota Magelang. Meski tidak menerima honor, pemerintah kota memberikan insentif bagi 735 orang 
anggota Satlinmas (data per Juli 2013) yang melakukan perjalanan dinas dalam kota sebesar Rp 30 ribu dan Rp 100 untuk perjalanan dinas luar kota. Selain itu, ada juga insentif berupa uang bantuan modal usaha Rp 2 juta, uang tali asih (purna tugas) Rp 1 juta, dan santunan kematian sebesar Rp 2 juta. Tetapi, malangnya, sejak 2012, bantuan itu dihentikan karena dilarang oleh Permendagri No. 39 Tahun 2012 tentang Perubahan Atas Permendagri No. 32 Tahun 2011 tentang Pedoman Pemberian Hibah dan Bantuan Sosial yang Bersumber dari Anggaran Pendapatan dan Belanja Daerah.

Soal honor dan dana bantuan operasional, misalnya, sangat kecil dan besarannya tidak pernah pasti. Anggaran Satlinmas diambil dari pos alokasi dana desa (ADD) atau pun alokasi anggaran kelurahan (AAK). Penentuan besarannya sangat tergantung pada hasil musyawarah di desa/kelurahan.

Sebagai contoh, Kalau di Kota Surabaya, lain lagi ceritanya, anggota Satlinmas berstatus tenaga kontrak. Pada 2013, mereka bergaji Rp 1,8 juta/bulan. Pada 2014 meningkat menjadi Rp 2,2 juta/bulan.

Selama ini, Satlinmas hanya mengandalkan tambahan pendapatan dari kebaikan hati dan uluran tangan warga. Misalnya, saat ada hajatan warga yang memerlukan bantuan pengamanan, di situlah ajang bagi anggota Satlinmas mendapat berkah tambahan penghasilan.

Persoalan menjadi kian kompleks dan rumit kalau kita telaah eksistensi Satlinmas dari sisi regulasi, tugas pokok dan fungsi (tupoksi), serta hal lain dalam konteks kekinian. Oleh karenanya, tulisan ini menjadi relevan. Reposisi dan revitalisasi peran dan fungsi Satlinmas kiranya perlu dilakukan. Sehingga, didapatkan pemahaman yang utuh tentang keberadaan fungsi sejati dari Satlinmas.

Agar mudah dibahas, patut juga diuraikan tentang latar belakang berdirinya Satlinmas. Sejarah perjalanan bangsa ini membuktikan, kehadiran Perlindungan Masyarakat (dulu disebut Pertahanan Sipil, disingkat Hansip) memiliki kontribusi yang positif.

Dimulai pada waktu pemerintahan Hindia Belanda, Pemerintah Belanda membentuk sebuah organisasi yang bertugas melindungi masyarakat dari serangan udara musuh. Pada waktu itu (1939) dikenal dengan nama Lucht Bescherming Deints atau LBD (Perlindungan Pemecah Udara).

Organisasi itu dibentuk dari tingkat pusat sampai daerah dan dikoordinasikan oleh pejabat pemerintahan sipil. Kegiatannya meliputi penerangan masyarakat, pemberitaan serangan udara musuh, perlindungan, penyamaran, pemadam kebakaran, pertolongan pertama penderita kecelakaan, pengungsian dan sebagainya. Kemudian, pada masa pendudukan Jepang, Pemerintah Jepang membentuk organisasi semacam LBD yang disebut Hansip pada 1943 (Istanto, 1992).

Sistem pertahanan Jepang pada waktu itu diarahkan untuk mengadakan pertahanan rakyat total dan untuk pengerahan rakyat, organisasi itu dibentuk sampai dengan pada lingkungan masyarakat yang terkecil dalam bentuk Gumi atau RT yang dikenal sekarang.

Organisasi bentukan Jepang itulah yang menjadi embrio Hansip, organisasi itu dirangkaikan dengan kepentingan pertahanan dan perlindungan masyarakat terhadap serangan musuh. Selain itu, ia juga dibebani tugas penjagaan keamanan, pengumpulan dana, pengaturan distribusi bahan makanan dan sebagainya.

Lalu, pada masa awal kemerdekaan, organisasi Hansip dilanjutkan eksistensinya. Pemerintah Indonesia menata dan mewadahi, mengerahkan, serta mengendalikan penyelenggaraan upaya pertahanan keamanan negara melalui suatu konsepsi Perlawanan Rakyat Semesta yang mengandung arti kesadaran, tekad, sikap dan pandangan rakyat Indonesia untuk melawan dan menghancurkan setiap bentuk ancaman.

Keikutsertaan seluruh rakyat Indonesia secara spontan dalam penyelenggaraan upaya pertahanan keamanan negara dengan maksud untuk membuka seluas-luasnya kepada warga negara agar tertampung guna ikut serta dalam upaya pembelaan negara ini diwadahi dalam organisasi Hansip dan Wanra (Perlawanan Rakyat). Perlu diketahui, Wanra didasarkan pada security defence approach, sedangkan Hansip didasarkan pada prosperity approach (Istanto, 1992:168).

Seiring berjalannya waktu, pada 20 Mei 1960 Indonesia resmi menjadi anggota International Civil Defence Organization (ICDO). Posisi Indonesia dalam organisasi internasional itulah yang kemudian mengilhami pembentukan organisasi Pertahanan Sipil (Hansip) dan organisasi Perlawanan Rakyat (Wankamra) secara nasional, dengan fungsi bidang perlindungan masyarakat, ketahanan nasional, pemerintahan, dan kesejahteraan rakyat.

Sejarah mencatat, organisasi Hansip di Indonesia pertama kali diatur oleh Keputusan Wakil Menteri Pertama Urusan Pertahanan/Keamanan No. MI/A/72/62 tertanggal 19 April 1962 tentang Peraturan Pertahanan Sipil dan sampai sekarang tanggal tersebut diperingati sebagai Hari Ulang Tahun Pertahanan Sipil di seluruh Indonesia.

Dalam rangka penyempurnaan organisasi Pertahanan Sipil dan sistem pembinaan potensi rakyat sebagai perwujudan dan kewajiban rakyat dalam usaha pembelaan negara, maka pada 12 Agustus 1972 lahirlah Keppres No. 55 Tahun 1972 tentang Penyempurnaan Organisasi Pertahanan Sipil dan Organisasi Perlawanan dan Keamanan Rakyat dalam Rangka Penertiban Pelaksanaan Sistem Pertahanan dan Keamanan Rakyat Semesta.

Dalam konteks itu, dengan apik Crouch (1988) mencandrakan bagaimana Orde Baru melakukan "pembinaan" seluruh potensi rakyat dalam hubungannya dengan pertahanan negara dan mobilisasi politik (lihat penjelasan Crouch dalam bukunya The Army and Politics in Indonesia. 
Bandingkan juga dengan tulisan Lee (2009) dalam (Un) Civil Society and Political Change in Indonesia).

Keppres tersebut menyatakan, perlindungan masyarakat (Linmas) merupakan fungsi utama dari pertahanan sipil yaitu mengorganisasikan rakyat dan membentuk Satlinmas untuk menanggulangi/mengurangi akibat-akibat dari serangan pihak musuh dari luar, bencana alam, dan bencana lainnya, agar kerugian jiwa dan materil dapat dihindarkan/dibatasi.

Maka, pada tanggal yang sama Organisasi Pertahanan Sipil yang semula dibina oleh Departemen Pertahanan Keamanan diserahkan kepada Departemen Dalam Negeri melalui Keppres No. 56 Tahun 1972 tentang Penyerahan Pembinaan Organisasi Pertahanan Sipil dari Departemen Pertahanan Keamanan kepada Departemen Dalam Negeri.

Seiring dengan perkembangan ketatanegaraan Republik Indonesia dan pertumbuhan Angkatan Bersenjata, maka pada 19 September 1982 lahirlah UU No. 20 Tahun 1982 tentang Ketentuan Pokok Pertahanan Negara di mana UU tersebut menguatkan posisi dan tugas pokok organisasi Hansip.

Dalam aturan itu Hansip melaksanakan fungsi Linmas dalam penanggulangan akibat bencana perang, bencana alam atau bencana lainnya maupun memperkecil akibat malapetaka dengan menempatkan Hansip sebagai komponen khusus di bidang pertahanan keamanan rakyat semesta.

Sebagai tindak lanjut Pasal 42 UU No. 20 Tahun 1982 yang mengamanatkan mobilisasi dan demobilisasi harus diatur dengan UU, maka pada 3 Oktober 1997 lahirlah UU No. 27 Tahun 1997 tentang mobilisasi dan demobilisasi yang menyebutkan, "mobilisasi dikenakan terhadap warga negara yang termasuk Perlindungan Masyarakat" sebagai komponen khusus kekuatan pertahanan keamanan negara yang mampu berfungsi membantu masyarakat menanggulangi bencana dan memperkecil akibat malapetaka.

Dalam Penjelasan Umum juga disebutkan mobilisan yang melaksanakan fungsi ketertiban umum, perlindungan rakyat, perlindungan masyarakat dan warga negara yang karena keahliannya diperlukan, serta awak sarana dan prasarana nasional yang tidak langsung membantu pertempuran diorganisasikan dalam perlawanan rakyat tidak bersenjata.

Namun, sejak dicabutnya UU No. 20 Tahun 1982 dan digantikan dengan UU No. 3 Tahun 2002 tentang Pertahanan Negara yang menempatkan Satlinmas sebagai komponen cadangan, maka sebagai dasar hukumnya organisasi Hansip yang pada saat itu telah berubah nomenklatur menjadi organisasi Linmas (berdasarkan Rapat Koordinasi Markas Wilayah Pertahanan Sipil Tahun 2000) kembali mengacu kepada Keppres No. 55 Tahun 1972 sehubungan Keppres tersebut belum dicabut atau diganti dengan aturan yang baru.
Merujuk aturan yang berlaku saat ini, ada beberapa tugas pokok yang diemban Satlinmas. Pertama, membantu upaya pertahanan negara. Menurut Pasal 1 Angka 4 dan Pasal 6 UU No. 27 Tahun 1997 tentang Mobilisasi, mobilisan adalah warga negara anggota Rakyat Terlatih, warga negara anggota Linmas, dan warga negara yang karena keahliannya dimobilisasi. Malah, pada UU No. 3 Tahun 2002 tentang Pertahanan Negara khususnya Pasal 8 Ayat 1 diterangkan, salah satu komponen cadangan pertahanan negara adalah Satlinmas. Patut diketahui, berkait dengan itu, dalam RUU Komponen Cadangan yang sedang digarap oleh Kementerian Pertahanan dan TNI, pada bagian komponen pendukung non-kombatan, elemen Hansip/Linmas dimasukkan menjadi bagian dari komponen pertahanan negara.

Kedua, membantu penanggulangan bencana. Dalam UU No. 24 Tahun 2007 tentang Penanggulangan Bencana, khususnya pada Pasal 4 Huruf a, Pasal 6 Huruf b, dan Pasal 8 Huruf b menyebutkan, tanggung jawab pemerintah dalam penyelenggaraan penanggulangan bencana meliputi perlindungan masyarakat dari dampak bencana. Dalam konteks itulah, Satlinmas memegang peranan penting.

Kemudian dalam Keppres No. 55 Tahun 1972 tentang Penyempurnaan Oraganisasi Pertahanan Sipil dan Organisasi Perlawanan dan Keamanan Rakyat dalam Rangka Penertiban Pelaksanaan Sistem Hankamrata pada Pasal 6 juga telah ditegaskan, tugas pokok Hansip adalah merencanakan, mempersiapkan, dan menyusun serta mengerahkan potensi rakyat dalam bidang perlindungan masyarakat untuk mengurangi/memperkecil akibat-akibat bencana perang/bencana alam serta mempertinggi ketahanan nasional.

Belakangan, melalui Keputusan Menteri Dalam Negeri No. 131 Tahun 2003 tentang Pedoman Penanggulangan Bencana dan Penanganan Pengungsi di Daerah, pada Pasal 1 Huruf d ditegaskan kembali, penanggulangan bencana dan penanganan pengungsi di daerah dilakukan secara berjenjang, meliputi Kepala Desa/Lurah selaku Kepala Satuan Hansip/Linmas.

Mereka bertanggung jawab mengoordinasikan dan mengendalikan kegiatan masyarakat dalam pelaksanaan penanggulangan bencana dan penanganan pengungsi di wilayah Desa/Kelurahan, mulai dari tahap sebelum, pada saat, dan sesudah terjadi bencana dan pengungsian.

Ketiga, membantu kegiatan pemilu/pemilukada. Dalam UU No. 8 Tahun 2012 tentang Pemilihan Umum Anggota Dewan Perwakilan Rakyat, Dewan Perwakilan Daerah, dan Dewan Perwakilan Rakyat Daerah, pada Pasal 152 Ayat 4 disebutkan, penanganan ketenteraman, ketertiban, dan keamanan di setiap TPS dilaksanakan oleh 2 (dua) orang petugas yang ditetapkan oleh PPS. 
Penjelasannya, petugas yang menangani ketenteraman, ketertiban, dan keamanan dalam ketentuan ini berasal dari satuan Hansip/Linmas. Tugas ini senyatanya juga tercantum dalam Pasal 13 Ayat 3 dari PP No. 6 Tahun 2005 tentang Pemilihan, Pengesahan Pengangkatan, dan Pemberhentian Kepala Daerah dan Wakil Kepala Daerah.

Keempat, membantu kegiatan sosial kemasyarakatan. Dalam keadaan normal, Satlinmas diikutsertakan dalam membantu kegiatan yang diselenggarakan oleh masyarakat. Sebagai contoh, kegiatan pernikahan di lingkungan setempat, kegiatan keagamaan, serta kegiatan-kegiatan lain yang diselenggarakan di lingkungannya bertugas.

Kelima, membantu memelihara ketentraman dan ketertiban masyarakat (kamtibmas). Dalam rangka memelihara kamtibmas, Satlinmas juga diikutsertakan dalam pengamanan wilayah serta ikut terlibat dalam kegiatan sistem keamanan lingkungan (siskamling).

\section{METODE PENELITIAN}

Tulisan yang berdasarkan kajian kepustakaan dan uji petik di lapangan ini menggunakan metode deskriptif dan dipadu dengan pendekatan kualitatif. Pendekatan kualitatif digunakan untuk menggali pelbagai perspektif tentang eksistensi Satlinmas, baik dari masyarakat, pegawai pemerintah yang menangani keberadaan Satlinmas, anggota satlinmas sendiri, maupun, pembuat kebijakan di tingkat pusat.

Adapun metode pengumpulan data dilakukan dengan mewawancarai sejumlah informan dan menelusuri pelbagai dokumen yang terkait, baik yang dikeluarkan oleh Ditjen PUM, Kemeterian Pertahanan, maupun pemerintah daerah, dan mengutipbeberapa pemberitaan yang dilansir media massa cetak nasional dan lokal.

\section{HASIL DAN PEMBAHASAN}

Kendati dalam beberapa peraturan sudah diterangkan posisi, eksistensi, peran, dan tupoksi Satlinmas, senyatanya Satlinmas masih digelayuti banyak persoalan. Pertama, perubahan nama dari Hansip menjadi Linmas. Sejauh ini tidak ada dasar hukum yang menyebutkan perubahan tersebut.

Dasar hukum yang kerap disebutkan adalah Surat Edaran Mendagri No. 340/2921/SJ tertanggal 20 Desember 2002 tentang Ketentuan Pakaian Seragam dan Atribut Pertahanan Sipil/Perlindungan Masyarakat.

Surat edaran itu sejatinya hanya mengatur soal atribut dalam pakaian seragam PNS Kementerian Dalam Negeri dan Pemerintah Daerah, bukan penetapan perubahan nama Hansip menjadi Linmas. Diduga, perubahan istilah Hansip menjadi Linmas hanyalah penghindaran terminologi militeristik yang melekat sedari zaman Orde Baru dulu.

Memasuki era reformasi, semua istilah yang berbau militer memang banyak dihilangkan, berubah menjadi istilah yang lebih sipilistik. Dalam konteks ini, termasuklah istilah Hansip menjadi Linmas. Namun, sayangnya, perubahan itu tidak dilandasi aturan hukum yang jelas (Rinakit, 2005; bandingkan juga dengan penjelasan Rüland, 2013).

Menjadi rancu lagi, dalam konteks internasional, justru istilah Hansip-lah yang lebih dikenal. Ini tercermin dengan berdirinya organisasi Hansip sedunia, ICDO (http://www.icdo.org/ Home.aspx?lng=2 (diakses pada 20 Desember 2013 pukul 9.52 wib). Organisasi itu pun mencantumkan, salah satu tupoksi Hansip (civil defence) adalah perlindungan masyarakat. Jadi, terminologinya bukan Linmas atau civil protection, melainkan Hansip. Linmas tidak ada contoh praktiknya di dunia internasional alias tidak dikenal.

Kedua, memang dalam Peraturan Menteri Dalam Negeri No. 1 Tahun 1991 tentang Pakaian Dinas disebutkan, setiap Senin semua pegawai Kementerian Dalam Negeri dan pemerintah daerah mengenakan seragam berwarna hijau bertuliskan Hansip/Linmas di dada kiri.

Tetapi, praktik di lapangan, utamanya daerah, tidaklah seragam. Di Sumatera Selatan, misalnya, semua PNS pemerintah provinsi mengenakan seragam putih (baju) hitam (celana/rok). Seragam hijau ala Hansip/Linmas sudah lama ditanggalkan.

Sebagai contoh, penggunaan seragam Linmas di Kota Surabaya berbeda dengan Linmas pada umumnya yang berwarna hijau muda. Di Surabaya, Satlinmas menggunakan warna hitam gelap. Sepintas warnanya tampak sama dengan warna seragam Brimob, Densus 88, atau pun Pasukan Katak yang dimiliki TNI Angkatan Laut. Alasan penggunaan seragam yang berbeda ini adalah untuk memberikan citra positif terhadap anggota Satlinmas supaya lebih dihargai dan dihormati. Tetapi, warna hijau tetap digunakan pada saat tertentu, seperti memperingati Ulang Tahun Satlinmas dan operasional sehari-hari Satlinmas di Kelurahan, RW, atau pun RT.

Persoalan pakaian seragam ini masih bisa diperpanjang ketika muncul pertanyaan, apakah semua PNS yang mengenakan seragam dengan atribut Linmas otomatis menjadi anggota Satlinmas? Padahal, dalam kesehariannya, tidak semua, malah kebanyakan PNS tidak mengerti apalagi terampil melaksanakan tugas pokok dan fungsi sebagaimana diemban anggota Satlinmas pada umumnya. Oleh karena itu, jawabannya, tentu tidak!

Namun, jawaban yang acap mengemuka tentang hal ini adalah pengaturan seragam ala Linmas yang diterapkan kepada PNS sekadar bentuk penghormatan Kementerian Dalam Negeri terhadap eksistensi Linmas yang telah lama berdiri. Di samping itu, Linmas adalah salah satu urusan yang dibina oleh Kementerian Dalam Negeri sejak diserahkan oleh Kementerian Pertahanan pada 1972 silam.

Ketiga, dasar hukum pembentukan Satlinmas. Sampai saat ini, pembentukan Satlinmas masih 
mengacu pada Keppres No. 55 Tahun 1972. Belum ada aturan baru yang memayungi Satlinmas.

Sandaran penggunaan istilah Linmas masih menggunakan beberapa regulasi lawas yang tentunya masih memakai istilah Hansip. Padahal, konsepsi dan filosofi yang dikandung Hansip dan Satlinmas adalah berbeda. Impaknya, ada kerancuan konsep dan filosofi di sana.

Celakanya, sampai saat ini belum ada regulasi yang dapat dijadikan pedoman, baik bagi satuan kerja perangkat daerah (SKPD) yang membidangi Linmas maupun aparat Satlinmas itu sendiri dalam melaksanakan tugas pokok dan fungsi secara utuh di lapangan.

Kementerian Dalam Negeri, melalui Direktorat Jenderal Pemerintahan Umum (Ditjen PUM), memang pernah mengajukan draf Peraturan Presiden (Perpres) tentang Satlinmas. Tetapi, "mandeg" di Sekretariat Negara tanpa diketahui penyebabnya dan kelanjutannya sampai hari ini.

Belakangan, awal 2013 lalu, Ditjen PUM berusaha mengajukan kembali regulasi tentang Satlinmas dalam bentuk Permendagri. Draf Permendagri itu sejatinya sudah rampung, tetapi belum disahkan secara resmi menjadi sebuah regulasi. Kendati begitu, dari segi isi, secara garis besar tidak ada perbedaan yang berarti antara draf Perpres dan Permendagri yang diajukan itu.

Kalau pun saat ini ada regulasi tentang Satlinmas, isinya masih bersifat parsial dan tetap rancu. Tidak mengatur secara detil dan tersendiri tentang eksistensi Satlinmas. PP No. 6 Tahun 2010 tentang Satuan Polisi Pamong Praja, misalnya, menyebutkan salah satu fungsi dan tugas satpol PP adalah perlindungan masyarakat, pelaksana perlindungan masyarakat serta fasilitasi dan pemberdayaan fungsi perlindungan masyarakat.

Malahan, dalam penjelasan Pasal 5 PP itu dengan terang menyebutkan, fungsi perlindungan masyarakat yang selama ini berada pada satuan kerja perangkat daerah (SKPD) Kesatuan Bangsa dan Perlindungan Masyarakat menjadi fungsi Satpol PP.

Kalau memang demikian, mengapa harus ada Satlinmas lagi? Mengapa fungsi itu tidak dijalankan saja oleh Satpol PP? Sehingga, tidak perlu lagi menambah banyak satuan di dalam SKPD yang pada akhirnya membuat pekerjaan menjadi tumpang tindih dan membebani anggaran saja.

Keempat, ulang tahun Satlinmas. Selama ini, hari lahir Satlinmas diperingati setiap 19 April. Aturan yang dirujuk adalah Keputusan Wakil Menteri Pertama Urusan Pertahanan/Keamanan No. MI/A/72/62 tertanggal 19 April 1962. Dasar hukum itu senyatanya patut dipertanyakan.

Pasalnya, dalam konsideran Keppres No. 128 Tahun 1962 tentang Perencanaan, Penyelenggaraan, Koordinasi, dan Pengawasan Pertahanan Sipil dan Perlawanan Rakyat, pada bagian Mengingat dicantumkan Keppres No. 48 Tahun 1962 tertanggal 19 Februari 1962 tentang Pembentukan Organisasi
Hansip dalam Usaha Mempertinggi serta Menggalang Kewaspadaan Nasional.

Mestinya, ulang tahun Satlinmas adalah 19 Februari 1962. Karena, pada waktu itulah pertama kali cikal bakal Hansip yang berubah menjadi Linmas terbentuk melalui Keppres No. 48 Tahun 1962. Bukan 19 April sebagaimana yang biasa diperingati selama ini.

Kelima, rekrutmen Satlinmas. Seperti diulas di bagian awal tulisan ini, kebanyakan anggota Satlinmas sudah berusia uzur. Oleh karenanya, dalam rekrutmen, mestinya sudah dibatasi ambang batas maksimal rekrutmen awal anggota Satlinmas adalah usia produktif, misalnya 45 tahun.

Selain itu, sejak awal lahirnya Hansip, rekrutmen keanggotaan Hansip/Linmas adalah sukarela (Ratnasari, 2013). Tetapi, di zaman sekarang yang materialistik, sangat sukar mengharapkan orang mau bekerja secara sukarela tanpa imbalan.

Karena sukarela dan tidak digaji, bagaimana pemerintah bisa menjamin eksistensi Satlinmas, terutama soal kesejahteraan. Sehingga, anggota Satlinmas perlu digaji dengan berpatokan pada kinerja dan beban kerja.

Menarik disimak pengalaman Kota Magelang dalam merekrut anggota Satlinmas. Berbeda dengan daerah lainnya, animo masyarakat untuk mendaftar sebagai anggota Satlinmas sangat tinggi, terutama menjelang Pemilu 2014. Selidik punya selidik, ternyata ada motif lain. Disinyalir, ada perselingkuhan politik antara anggota Satlinmas dengan para caleg yang akan berlaga pada Pemilu 2014.

Seperti diketahui, UU No. 8 Tahun 2012 Pasal 152 Ayat 4 menerangkan, petugas yang menangani ketentraman dan ketertiban serta keamanan di TPS berasal dari Satlinmas. Selain itu, Peraturan Menteri Dalam Negeri No. 62 Tahun 2008 tentang Standar Pelayanan Minimal Bidang Pemerintahan Dalam Negeri menyebutkan, setiap RT ditempatkan minimal 1 orang anggota Linmas. Dari kedua aturan itu ada celah bagi caleg dan anggota Satlinmas yang dapat dimanfaatkan untuk "bermain politik".

Keenam, eksistensi Satlinmas dalam konteks penanggulangan bencana. Di satu sisi, sejak awal tugas pokok Satlinmas adalah melaksanakan kegiatan penanganan bencana. Hal itu semakin menguat dengan keluarnya Surat Edaran Menteri Dalam Negeri No. 362/4396/SJ tertanggal 11 Desember 2009 tentang Pemberdayaan Satlinmas dalam Membantu Kegiatan Penanggulangan Bencana Banjir dan Tanah Longsor.

Sementara, di sisi lain, pembentukan Badan Nasional Penanggulangan Bencana (BNPB) dan keluarnya UU No. 24 Tahun 2007 jelas-jelas telah mengambil alih peran Satlinmas. Tugas Linmas saat terjadi bencana alam tidak lagi terlihat. Hadirnya BNPB senyatanya juga telah mereduksi peran Satlinmas dalam memobilisasi penanggulangan bencana. 
Sebab, secara asas, Satlinmas mengedepankan kerja sukarela, bukan bayaran. Kalau terjadi bencana, aspek mobilisasi sukarelawan bisa berubah menjadi mobilisasi berbasis komersialisme, dan BNPB senyatanya tidak punya sukarelawan, seperti halnya Satlinmas.

Para pejabat yang membidangi urusan Linmas pun kerap berkelit dan mengatakan, tidak ada tumpang tindih antara tugas Satlinmas dan BNPB atau pun Badan Penanggulangan Bencana Daerah (BPBD). Memang, bisa dikatakan demikian. Sebab, selama ini sangat sedikit atau mungkin tidak pernah BNPB/BPBD menggunakan aparat Satlinmas di lapangan ketika terjadi bencana.

Pasalnya, banyak anggota Satlinmas yang tidak terlatih dalam menanggulangi bencana. Sekadar perbandingan, Hal ini sangat berbeda dengan peran Satlinmas yang berlaku di Selandia Baru. Di sana, peran Satlinmas cukup sentral, selain terlatih, Satlinmas juga diberi kewenangan besar dalam melakukan koordinasi dengan pihak terkait guna menangani bencana secara cepat dan tepat. (keterangan lebih lanjut, silakan baca penjelasan Lee, 2010:565-576).

Belum lagi, kebanyakan anggota Satlinmas sudah uzur. Sehingga, tidak berperan ketika penanggulangan bencana dilakukan oleh BNPB/BPBD. Jadi, kalau memang tidak berperan, bagaimana bisa dikatakan ada tumpang tindih kewenangan dan peran di lapangan?

Ketujuh, citra Satlinmas. Rendahnya citra Satlinmas di mata masyarakat akibat opini publik yang terbentuk dari media cetak maupun elektronik/audiovisual yang hanya menampilkan sisi negatif Satlinmas.

Akibatnya, masyarakat tidak lagi melihat Satlinmas sebagai aparatur negara yang memunyai peran dan fungsi penting, tetapi hanya sebagai petugas yang tidak memunyai pekerjaan dan keahlian apa-apa selain berjaga di pos ronda.

Namun, kondisi itu sudah direspons dengan baik oleh Menteri Dalam Negeri dengan mengirimkan surat kepada Menteri Komunikasi dan Informatika No. 340/897/SJ perihal Penertiban Tayangan tentang Sosok Anggota Hansip/Linmas di Media Televisi pada 4 Maret 2010. Surat itu adalah respons atas maraknya penayangan sosok anggota Hansip/Linmas di media televisi yang terkesan mendeskreditkan/melecehkan peran dan fungsi Satlinmas sebagai lembaga pemerintah.

Sebagai tindak lanjut, guna mengembalikan citra Satlinmas di mata masyarakat Kementerian Dalam Negeri pun telah menyelenggarakan berbagai kegiatan mengenai pencitraan Satlinmas di media massa, cetak dan elektronik, sehingga masyarakat dapat mengetahui arti pentingnya peran dan fungsi anggota Satlinmas yang sebenarnya.

Kedelapan, penggabungan Satlinmas dan Satpol PP. Masuknya urusan Linmas ke dalam Satpol PP menimbulkan persoalan tersendiri. Di atas telah disinggung, Linmas itu adalah fungsi bukan organisasi. Dalam konteks itu, penggabungan hanya menimbulkan tumpah tindih urusan. Penyatuan itu telah menimbulkan "gejolak" baru baik di internal Kesbangpol, induk awal Linmas, maupun Pol PP sendiri sebagai tempat baru Satlinmas.

Fakta di lapangan menunjukkan, masih banyak SKPD Kesbangpol dan Linmas di daerah yang tidak/belum bergabung dengan Pol PP. Alasannya, secara tupoksi dan filosofi ada perbedaan signifikan antara Satlinmas dengan Satpol PP.

Pol PP itu tugasnya menegakkan peraturan daerah, sementara Linmas melindungi masyarakat dari marabahaya bencana alam. Dari sisi filosofi, Linmas bersifat persuasif, sementara Pol PP bersifat represif. Dengan alasan itu, Provinsi Jawa Tengah, Kota Magelang dan Kota Surabaya, misalnya, masih mempertahankan Linmas bergabung dengan SKPD Kesbangpol.

Selain itu, ketika bergabung dengan Pol PP, Kesbangpol akan kehilangan satu bidang urusan dalam organisasinya. Impaknya, status SKPD yang disandang Kesbangpol bisa turun menjadi Kantor (setingkat eselon tiga).

Ditjen PUM pernah mengusulkan, untuk bidang urusan Linmas bisa saja diganti dengan bidang urusan yang ada di Ditjen PUM, diadopsi saja struktur organisasi di Ditjen PUM yang ada bidang Linmasnya. Tetapi, oleh daerah, usulan itu ditolak karena bidang urusan yang dikerjakan Ditjen PUM sebagian besar berbeda dengan SKPD Pol PP di daerah.

Kalau pun di antara mereka ada yang bergabung, praktiknya tetap juga menimbulkan persoalan. Banyak SKPD Kesbangpol yang tidak menyerahkan personil dan peralatan kepada SKPD Pol PP, sehingga Pol PP mengalami kesulitan dalam melaksanakan tupoksinya. Belum lagi, tidak sedikit personil Kesbangpol yang benar-benar enggan pindah ke Pol PP.

\section{SIMPULAN}

Melihat pelbagai persoalan yang diuraikan di atas, banyak hal yang mesti diupayakan oleh pelbagai pihak, utamanya Ditjen PUM Kementerian Dalam Negeri untuk membenahi Satlinmas. Dari sekian banyak masalah, agaknya kedudukan dan tupoksi Satlinmas adalah yang paling menonjol untuk segera dicarikan solusinya.

Kalau ditelaah secara saksama, merujuk pada pelbagai peraturan yang ada, tupoksi utama Satlinmas adalah penanggulangan bencana. Adapun tupoksi yang lain seperti pengaman pemilu dan pemilu kepala daerah, sifatnya hanya insidentil.

Malah, kalau hanya terlibat sebagai penjaga ketertiban dalam pemilu, harusnya tidak perlu dilembagakan khusus, anggota Satlinmas cukup direkrut oleh KPU/KPUD saja. Dengan begitu, jelas eksistensi Satlinmas menjadi mubazir setelah adanya $\mathrm{BNPB} / \mathrm{BPBD}$. Apalagi di kementerian lain juga ada 
satuan yang memiliki tugas dan peran yang sama dengan Satlinmas.

Kementerian Sosial, misalnya, punya satuan berjuluk Taruna Siaga Bencana (Tagana) yang tersebar di 33 provinsi, dan saat ini sudah terdapat 29 ribu relawan. Kementerian Sosial pun menyiapkan sarana latihan penanganan bencana alam bernama Tagana Center, sehingga masyarakat siap menghadapi bencana yang kapan saja datang.

Tagana Center merupakan tempat ideal latihan penanganan bencana. Kementerian Sosial sebagai lembaga negara memberikan logistic supporting system, termasuk capacity building, manajemen bencana dengan membangun pusat pelatihan yang lengkap dengan simulasi bencana di kawasan Sentul, Bogor, Jawa Barat. Sementara, Satlinmas tidak punya sarana latihan seperti itu.

Selain itu, dengan berubahnya paradigma pemerintahan dari sentralistik ke demokratis desentralistik, maka menempatkan urusan Linmas di jajaran Kementerian Dalam Negeri dan pemerintah daerah menjadi kurang relevan lagi.

Kita mesti jujur mengatakan, yang paling membutuhkan keberadaan Linmas sekarang ini sebenarnya adalah TNI dan Kementerian Pertahanan, karena dianggap masih relevan dengan doktrin Pertahanan Rakyat Semesta.

Apalagi RUU Komponen Cadangan yang sedang disusun oleh Kementerian Pertahanan dan TNI memasukkan elemen Linmas sebagai komponen pendukung non-kombatan dan menjadi bagian penting dari komponen pertahanan negara.

Untuk itu, sudah saatnya dipikir ulang tentang eksistensi Satlinmas di masa depan. Sebaiknya diadakan workshop nasional yang melibatkan Kementerian Dalam Negeri, Kementerian Pertahanan, BNPB/BPBD dan pemerintah daerah guna mengkaji secara komprehensif dan holistik eksistensi Satlinmas.

Sehingga, didapatkan rumusan yang utuh tentang konsepsi, tugas pokok dan fungsi, serta tingkat obyektivitas tentang perlu tidaknya Satlinmas dipertahankan.

\section{DAFTAR PUSTAKA}

Crouch, Harold. 1988. The Army and Politics in Indonesia. Ithaca: Cornell University Press

Lee, Bo Yao. 2010. "Working Together, Building Capacity: A Case Study of Civil Defence Emergency Management in New Zealand". Journal of Disaster Research Vol 5 No. 5 pp 565-576

Lee, Verena Beittinger. 2009. (Un) Civil Society and Political Change In Indonesia: A Contested Arena. New York: Routledge

Istanto, F. Sugeng. 1992. Perlindungan Penduduk Sipil dalam Perlawanan Rakyat Semesta dan Hukum Internasional. Yogyakarta: Andi Offset

Ratnasari, Desi. 2013. "Studi tentang Proses Rekrutmen Tenaga Kerja Perlindungan Masyarakat (Linmas) di Badan Kesatuan Bangsa, Politik dan Perlindungan Masyarakat Kabupaten Malinau”.
Jurnal Pemerintahan Integratif. Vol 1 No. 1 hal 7590

Rinakit, Sukardi. 2005. The Indonesian Military After the New Order. Copenhagen: NIAS

Rüland, Jürgen (eds). 2013. The Politics of Military Reform: Experiences from Indonesia and Nigeria. Heidelberg: Springer 
